\title{
KORESPONDENSI PREFERENSI DAN KARAKTERISTIK TIPE WISATAWAN GRUP PADA KAWASAN AGROWISATA
}

\section{The Correspondence between \\ Preference and Characteristics of \\ Group Tourists Types in \\ Agrotourism Area}

\section{Ni Made Diah Ayu Kendran \\ Sekolah Arsitektur, Perencanaan dan Pengembangan Kebijakan (SAPPK), Institut Teknologi Bandung (ITB) Email: diahayukendran88@students.itb. ac.id}

\section{Hanson Endra Kusuma \\ Sekolah Arsitektur, Perencanaan dan Pengembangan Kebijakan (SAPPK), Institut Teknologi Bandung (ITB) \\ Email: hangsong@ar.itb.ac.id}

\section{Annisa Safira Riska}

Sekolah Arsitektur, Perencanaan dan Pengembangan Kebijakan (SAPPK), Institut Teknologi Bandung (ITB)Email: annisasafira@ar.itb.ac.id

\section{ABSTRACT}

Facility planning will be successful if every process always consider the user and activities aspects. This aspects also applies to the agrotourism area, where tourist preference and segmentation can be used to understand visitor desires. This research aims to identify preferences and characteristics of the tourist segmentation in the visited agrotourism areas. This research used a grounded theory approach with qualitative exploratory methods. Data was collected online in an open-ended and close-ended questionnaire which was analyzed in 3 steps; open coding, axial coding, and selective coding. Based on the analysis results, tourists' preference for visiting agrotourism area were to enjoy natural environment and do various recreational activities. The study also found the tourist characteristics was dominated by visitors who come in groups with close relationship of family and friends. The characteristics of these tourists can be used as a basis of harmonisation for determining the criteria of facilities in agrotourism where the implemented design can give attention to the sustainability (lifecycle) of tourist attraction from natural and economic aspect.

Keywords: agrotourism visitors, market segmentation, tourist characteristics, tourist preferences,

\section{PENDAHULUAN}

Perkembangan sektor pariwisata Indonesia dalam beberapa tahun terakhir menunjukkan kinerja yang signifikan. Berdasarkan data dari United Nations World Tourism Organization (UNWTO) di tahun 2019, Indonesia berada di urutan ke-4 sebagai negara tujuan wisata Asia dan Pasifik dengan kunjungan mencapai 15,8 juta wisatawan. Pariwisata Indonesia memiliki potensi yang besar untuk berkembang. Berbagai jenis daya tarik wisata dengan jenis wisatanya mempunyai kedudukan yang sangat penting dalam menarik minat kunjungan wisatawan ke destinasinya (Sunaryo, 2013; Febriana dan Kaswanto, 2015; Dradjat dan Mugnisjah, 2017).

Pergeseran kecenderungan minat wisatawan terhadap destinasi alam, menyebabkan munculnya berbagai jenis destinasi baru yang memanfaatkan kondisi alam sebagai daya tarik utamanya. Salah satu wisata alam yang mulai berkembang saat ini adalah wisata agro atau yang lebih populer dikenal dengan istilah agrowisata. Agrowisata merupakan sebuah model pengembangan wisata yang memadukan antara kegiatan pertanian dan kegiatan wisata. Pengembangan suatu wisata dapat dikatakan berhasil atau tidak, dilihat dari jumlah kunjungan wisatawan yang datang ke objek tersebut.

Pemangku kepentingan wisata dalam menjalankan usahanya harus memiliki rumusan yang jelas terkait keberlanjutan objek wisata yang akan dikembangkan. Jika ditinjau dari segi wisatawan, disebutkan bahwa setiap wisatawan itu berbeda dan membawa pengalaman, motivasi dan keinginan yang berbeda pula (Cooper, et al 2005). Maka dari itu, penetapan segmentasi pasar untuk mengetahui keinginan dari kelompok yang sejenis menjadi penting untuk menetapkan fokus wisatawan yang akan disasar.
Segmentasi pasar dapat didefinisikan sebagai suatu skema pembagian pasar ke dalam kelompok wisatawan secara tegas, yakni tiap kelompok dipilih atau ditetapkan sebagai target pasar yang kemudian akan berpengaruh terhadap stategi pemasaran (Kotler dan Armstrong, 2006). Dalam kepariwisataan, melakukan studi terkait segmentasi merupakan suatu keharusan untuk mendapatkan pendekatan yang paling efektif kepada masing-masing segmen pasar yang akan dijadikan target. Segmentasi pasar dalam Ginting et al (2015) dapat dibagi menjadi 4 kategori besar, yaitu berdasarkan geografi, sosio-ekonomi demografi, psikografi, dan perilaku.

Pembagian wisatawan berdasarkan kategori psikografi menurut Plog dalam Pitana dan Gayatri (2005) menjelaskan bahwa populasi wisatawan terdiri dari dua kelompok ekstrim, yaitu allocentric dan psychocentric. Di antara allocentric (venturer) dan psychocentric (depenable) terdapat empat tipe lain, dengan rincian yakni dua tipe pertama cenderung dekat ke allocentric dan dua tipe berikutnya cenderung dekat ke psychocentric. Tipe tersebut adalah near-allocentric, mid-allocentric (centric-venturer), midpsychocentric dan near-psychocentric.

Menurut Suprapti (2010) untuk memperoleh manfaat yang maksimal dari suatu atau beberapa segmen pasar, sebuah segmen pasar harus memenuhi beberapa persyaratan, yakni dapat diukur (measurable), dapat dijangkau (accessible), ukurannya cukup besar (substantial), dapat dibedakan (differentiable), serta dapat dilaksanakan (actionable).

Berdasarkan penjabaran di atas, dapat dirangkum bahwa pengetahuan terkait segmentasi pasar merupakan keharusan terhadap keberlanjutan (lifecycle) suatu pengembangan kawasan wisata. Maka dari itu, penelitian ini dilakukan dengan tujuan untuk lebih memahami preferensi dan karakteristik segmentasi pasar wisatawan 
pada kawasan agrowisata. Preferensi yang dimaksud berkaitan dengan motivasi utama responden untuk berkunjung ke agrowisata. Berbeda halnya dengan karakterisitk wisatawan yang diterkaitkan dengan data kondisi demografi responden, mulai dari jenis pekerjaan, durasi kunjungan, kendaraan yang digunakan hingga mitra yang diajak berkunjung.

\section{METODE PENELITIAN}

Pendekatan yang digunakan dalam penelitian ini adalah grounded theory dengan metode kualitatif yang bersifat eksploratif. Menurut Creswell (2007), grounded theory merupakan suatu metode penelitian kualitatif dengan tujuan untuk menghasilkan teori dan penjelasan umum dari sebuah fenomena berdasarkan informasi yang diperoleh dari responden. Informasi berupa data tersebut kemudian dianalisis, ditafsirkan, dan disusun menjadi sebuah model hipotesis. Selain itu, penelitian ini termasuk dalam penelitian dengan sifat eksploratif yang bertujuan untuk menggali pemahaman terhadap objek penelitian secara lebih mendalam, mencari kemungkinan untuk melakukan penelitian yang lebih spesifik, dan mengembangkan metode yang dapat digunakan pada penelitian lanjutan (Babbie, 2007). Dalam penelitian ini, data yang diperoleh berupa informasi mengenai preferensi serta karakteristik responden yang berkunjung pada kawasan agrowisata.

\section{Metode Pengumpulan Data}

Pengumpulan data dilakukan secara daring (online) menggunakan Google Form dalam bentuk kuesioner. Penyebaran kuesioner dilakukan dengan teknik snowball sampling. Teknik snowball sampling merupakan proses pemilihan sampel dengan memanfaatkan jaringan. Responden merupakan individu yang dapat menggunakan dan mengerti internet secara baik, dapat mengakses kuesioner dan dengan suka rela berpartisipasi sebagai responden. Kuesioner daring dibagikan secara bebas kepada rekan peneliti untuk disebarkan kembali melalui media sosial. Pengisian kuesioner tidak ditentukan bagi suatu populasi dengan kelompok usia, jenis kelamin atau wilayah tertentu, sehingga bersifat nonrandom/ convenience sampling.

Pengambilan data melalui kuesioner daring dilakukan mulai dari 3 September 2020 dan ditutup pada 15 September 2020 dengan total responden yang diperoleh sebanyak 106 responden. Adapun rincian jenis kelamin responden, yakni sebanyak 69 orang perempuan dan 37 orang laki-laki. Usia responden berkisar antara 18 tahun hingga 57 tahun. Tingkat pendidikan akhir mulai dari SMA hingga Pasca-Sarjana. Jenis pekerjaan responden terbagi menjadi 6 kategori, yakni pegawai negeri 12 orang, karyawan swasta 32 orang, pengusaha/wirausaha 5 orang, pegawai kontrak 5 orang, arsitek 2 orang, dan siswa/mahasiswa 50 orang. Pengeluran per-bulan responden berkisar antara kurang dari Rp 3 juta sampai dengan antara Rp 6-12 juta. Responden berasal dari beberapa pulau di Indonesia dengan rincian Bali 73 orang, Jawa 27 orang, Sumatera 4 orang, dan Kalimantan 2 orang.

Pertanyaan pada kuesioner daring disusun secara tertutup dan terbuka. Pertanyaan tentang atribut responden seperti jenis kelamin, pendidikan terakhir, jenis pekerjaan dan pengeluaran menggunakan pertanyaan yang bersifat tertutup (close-ended), sedangkan pertanyaan tentang alasan berkunjung, kegiatan yang dilakukan serta kegiatan yang berkesan ketika mengunjungi kawasan agrowisata menggunakan pertanyaan yang bersifat terbuka (open-ended). Pada bagian pertanyaan terbuka, responden memberikan jawaban berdasarkan pengalaman mereka terhadap kegiatan maupun alasan ketika berkunjung ke agrowisata.

Jenis ataupun kategori agrowisata yang disebutkan dan dinilai oleh responden tidak dibatasi pada wilayah ataupun skala tertentu. Responden dapat menyebutkan secara bebas nama dan lokasi agrowisata yang pernah dikunjungi. Berikut pada Tabel 1 merupakan pengkategorian agrowisata yang pernah dikunjungi responden.

Tabel 1. Kategori Agrowisata yang Pernah Dikunjungi Responden

\begin{tabular}{clc}
\hline No. & \multicolumn{1}{c}{ Kategori Agrowisata } & $\begin{array}{c}\text { Jumlah } \\
\text { Responden }\end{array}$ \\
\hline 1. & Hortikultura & 52 \\
2. & Perkebunan & 16 \\
3. & Perhutanan & 15 \\
4. & Tanaman Pangan & 16 \\
5. & Hortikultura dan Perkebunan & 1 \\
6. & Hortikultura dan Perhutanan & 1 \\
7. & Hortikultura dan Perikanan & 1 \\
8. & Hortikulturan dan Peternakan & 2 \\
9. & Perkebunan dan Tanaman & 1 \\
& Pangan & \\
10. & Hortikultura, Perkebunan, & 2 \\
& dan Peternakan & $\mathbf{1 0 6}$ \\
\hline
\end{tabular}

Kategori agrowisata hortikultura merupakan jenis agrowisata yang objek utamanya berasal dari keindahan taman bunga, kebun buah-buahan, dan sayur-sayuran. Selain itu, aktivitas yang ditawarkan berkaitan dengan pengetahuan dan pengalaman seperti cara memetik buah sendiri hingga melihat proses pengolahannya dengan menggunakan berbagai teknologi. Contoh agrowisata kategori hortikultura berdasarkan jawaban responden, yakni The Sila's Agrotourism - Bali (frekuensi: 12) dan Agrowisata Kusuma Batu - Malang (f:12).

Kategori agrowisata perkebunan merupakan agrowisata yang menawarkan keindahan perkebunan yang dilengkapi dengan udara yang sejuk. Contoh agrowisata ini berdasarkan jawaban responden meliputi Agrowisata Alas Harum - Bali (f:3) yang menawarkan panorama perkebunan kopi dan keindahan perkebunan teh di Agrowisata Rancabali - Bandung (f:4). Kategori agrowisata perhutanan merupakan agrowisata yang bentuk wisatanya tekait dengan hutan produksi ataupun hasil tanaman hutan yang dalam pengembangannya lebih dikenal sebagai suaka margasatwa, cagar alam dan kebun raya. Berdasarkan jawaban responden jenis agrowisata ini dapat dijumpai pada Kebun Raya Bedugul (f:9). Bentuk wisata dari kategori agrowisata tanaman pangan adalah agrowisata yang memperkenalkan kepada wisatawan mengenai komoditas pertanian tanaman pangan dari lahan kering dan basah. Kegiatan yang ditawarkan meliputi teknik menanam padi di sawah ataupun menanam jagung, kedelai dan sebagainya pada lahan kering. Contoh agrowisata yang termasuk kategori tanaman pangan, yakni Agrowisata Jatiluwih - Bali (f:9) dan Agrowisata Kertalangu - Bali (f:3). 


\section{Metode Analisis Data}

Metode analisis yang digunakan dalam penelitian ini adalah analisis isi (content analysis), analisis distribusi, analisis korespondensi, dan analisis klaster (cluster analysis). Pertanyaan terbuka terkait alasan berkunjung dan semi terbuka terkait hubungan pengguna, jumlah mitra, moda transportasi, durasi kunjungan, dan jenis pekerjaan dilakukan analisis dengan tahapan sebagai berikut.

1. Tahap pertama (open coding), merupakan tahap yang diawali dengan proses mengindentifikasi segmen makna dari jawaban responden ke dalam bentuk kode. Kode tersebut kemudian dikelompokkan menjadi kategori dengan kata yang lebih umum dan memiliki kedekatan makna ataupun sifat yang sama. Pada tahap ini, pengkategorian dilakukan dengan berdiskusi bersama teman sehingga pilihan kata yang dibuat tidak bias. Hasil dari kategori selanjutnya didistribusikan menggunakan analisis distribusi untuk mengetahui frekuensi kategori dari pertanyaan yang diajukan.

2. Tahapan kedua (axial coding), merupakan tahap eksplorasi untuk mengetahui hubungan korespondensi antar kategori. Pada tahapan ini analisis dilakukan dengan bantuan software statistik pengolahan data. Adapun data kategori yang digunakan sebagai data input (variabel) dapat dibedakan menjadi 2 jenis, yakni data kategori (kategori yang didapat berdasarkan pertanyaan closeended) dan data kosong satu (kategori yang didapat berdasarkan pertanyaan open-ended). Selain itu, dilakukan juga analisis klaster untuk melihat pengelompokan kategori yang memiliki kesamaan karakteristik.

3. Tahapan terakhir (selective coding), merupakan tahap penyusunan model hipotesis berdasarkan hasil analisis korespondensi yang telah didapatkan dari tahap axial coding.

\section{HASIL DAN PEMBAHASAN}

\section{Preferensi Wisatawan}

Tahap pertama dalam analisis isi, yakni open coding mengenai preferensi wisatawan yang didapatkan dari jawaban responden terkait alasan berkunjung ke agrowisata. Pernyataan tersebut kemudian dianalisis segmen maknanya dan dipilih kode yang memiliki makna sama. Contoh pemberian kode terhadap pernyataan responden dapat dilihat dalam kutipan berdasarkan hasil kuesioner berikut ini.

"karena ingin tahu lebih banyak". (Responden nomor: 18, jenis kelamin perempuan, usia 33 tahun)

"mencari tempat sejuk, asri dengan pemandangan perkebunan". (R:32, perempuan, 25 tahun)

"berlibur dengan keluarga, menghadiri acara keluarga, silaturahmi dengan keluarga yang didukung suasana alam indah dan cuaca sejuk". (R:68, laki-laki, 26 tahun)

"karena rekomendasi beberapa teman, yang mengatakan bahwa pada saat itu agrowisata batu merupakan tempat yang populer". (R:36, perempuan, 18 tahun)

"dekat dengan rumah". (R:4, perempuan, 24 tahun)
Berdasarkan kutipan di atas, akan didapatkan kode "ingin tahu", "sejuk", "asri", "alami", "liburan", "kumpul keluarga", "acara keluarga", "indah", "rekomendasi", "populer", dan "dekat rumah".

Temuan kode-kode hasil open coding kemudian dikelompokkan menjadi beberapa kategori yang akan dianalisis. Pengelompokan kode dan penamaan kategori dilakukan dengan diskusi bersama teman sehingga dapat meminimalkan bias dalam penamaan kategori. Kode yang telah didapatkan dari pernyataan alasan berkunjung dikelompokkan berdasarkan kategori yang telah ditentukan sebagaimana Tabel 2 di bawah ini.

Tabel 2. Proses Open Coding pada Alasan Responden Berkunjung ke Agrowisata

\begin{tabular}{|c|c|c|}
\hline Pertanyaan & Kode & Kategori \\
\hline \multirow{21}{*}{$\begin{array}{c}\text { Alasan } \\
\text { Berkunjung }\end{array}$} & Dekat rumah & \multirow{3}{*}{ Aksesibilitas } \\
\hline & Dekat objek lain & \\
\hline & Searah tujuan & \\
\hline & Kumpul keluarga & \multirow{3}{*}{$\begin{array}{c}\text { Interaksi } \\
\text { sosial }\end{array}$} \\
\hline & Acara keluarga & \\
\hline & Diajak ortu & \\
\hline & Wisata & \multirow{3}{*}{$\begin{array}{l}\text { Kegiatan } \\
\text { rekreatif }\end{array}$} \\
\hline & Liburan & \\
\hline & Belanja & \\
\hline & Tersedia fasilitas & $\begin{array}{l}\text { Kelengkapan } \\
\text { fasilitas }\end{array}$ \\
\hline & Sejuk & \multirow{4}{*}{$\begin{array}{l}\text { Lingkungan } \\
\text { alami }\end{array}$} \\
\hline & Nyaman & \\
\hline & Alami & \\
\hline & Dingin & \\
\hline & Tugas kantor & \multirow{3}{*}{$\begin{array}{c}\text { Pengerjaan } \\
\text { tugas }\end{array}$} \\
\hline & Tugas sekolah & \\
\hline & Tugas kuliah & \\
\hline & Ingin tahu & \multirow{2}{*}{$\begin{array}{c}\text { Pengingkatan } \\
\text { wawasan }\end{array}$} \\
\hline & Pengalaman baru & \\
\hline & Populer & \multirow{2}{*}{ Populer } \\
\hline & Rekomendasi & \\
\hline
\end{tabular}

Berdasarkan proses pengkategorisasian kode di atas, didapatkan 8 kategori terkait alasan responden berkunjung ke agrowisata. Setiap kategori kemudian dianalisis pendistribusiannya sehingga didapatkan frekuensi untuk melihat kategori yang lebih dominan dalam mengunjungi agrowisata (Gambar 1).

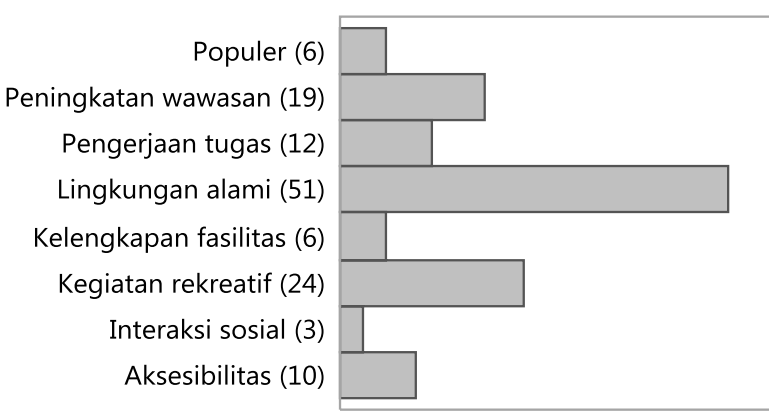

Gambar 1. Frekuensi Alasan Berkunjung ke Agrowisata

Berdasarkan hasil analisis distribusi pada Gambar 1, alasan responden yang menjadi preferensi untuk berkunjung ke agrowisata, didominasi oleh kategori 
lingkungan alami (f:51) yang dilanjutkan dengan kegiatan rekreatif (f:24), peningkatan wawasan (f:19), pengerjaan tugas (f:12), aksesibilitas (f:10), populer (f:7), kelengkapan fasilitas (f:6) dan interaksi sosial (f:3).

\section{Karakteristik Wisatawan}

Pengetahuan mengenai karakteristik wisatawan sebagai strategi pendekatan segmentasi pasar menjadi sebuah keharusan untuk mengetahui fokus konsumen yang akan disasar (Assauri, 2015). Berdasarkan teori yang telah dipaparkan sebelumnya, disebutkan bahwa segmentasi pasar terbagi menjadi empat kategori besar, yaitu geografi, sosio-ekonomi demografi, psikologi dan prilaku. Maka, analisis open coding akan dilanjutkan dengan tahapan kedua, yakni axial coding melalui analisis korespondensi. Berikut merupakan beberapa hasil analisis korespondensi tipe 1 (antar data kategori) dan tipe 2 (antara data kategori dan data kosong satu) yang memiliki nilai pearson (p) signifikan serta dapat mendukung pengetahuan terkait karakteristik wisatawan pada agrowisata. Nilai pearson (p) merupakan nilai yang menunjukkan kemungkinan prediksi hubungan korelasi antara 2 kategori yang sedang dianalisis. Jika nilai pearson (p) yang dihasilkan lebih rendah atau sama dengan $5 \%(\mathrm{p}<0.05)$ hubungan korelasi antara 2 kategori disebut dapat dinyatakan signifikan secara statistik.

\section{Karakter Wisatawan Berkelompok}

Berdasarkan hasil analisis korespondensi klaster antara alasan berkunjung dan hubungan pengguna $(\mathrm{p}=0.18)$ pada Gambar 2, terlihat bahwa karakter pengunjung yang datang ke agrowisata adalah tipe wisatawan berkelompok. Wisatawan berkelompok ini dapat dibedakan menjadi berkelompok dengan hubungan kedekatan keluarga (f:48) dan hubungan kedekatan teman (f:58). Responden tipe berkelompok-keluarga yang datang ke agrowisata memiliki kecenderungan preferensi berkunjung karena tempatnya populer (f:6), untuk menikmati lingkungan alami (f:51), kegiatan rekreatif (f:24) dan peningkatan wawasan (f:19). Sementara itu, responden tipe berkelompok-teman datang ke agrowisata dengan dominasi preferensi mengerjakan tugas (f:12).

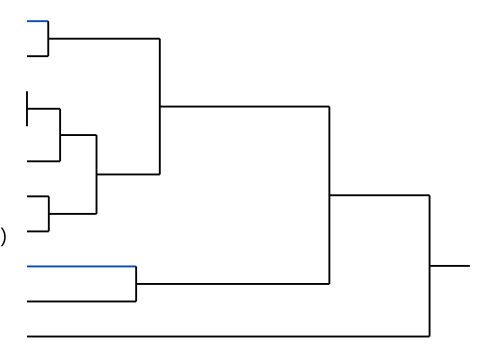

Gambar 2. Dendogram Korespondensi Alasan Berkunjung dan Hubungan Pengguna

Kategori antara hubungan pengguna dan jumlah mitra $\left(\mathrm{p}=0.0008^{*}\right)$ pada Gambar 3, memiliki hasil korespondensi klaster, yakni responden tipe berkelompok-keluarga yang datang ke agrowisata cenderung terdiri dari 2-5 orang (f:42). Sedangkan tipe berkelompok-teman didominasi datang dengan lebih dari 5 orang (f:51) atau 1 orang teman (f:13).

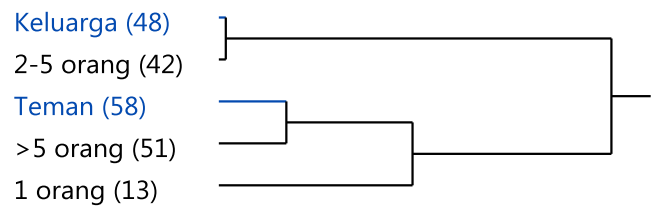

Gambar 3. Dendogram Korespondensi Hubungan Pengguna dan Jumlah Mitra

Korespondensi klaster antara hubungan pengguna dan moda transportasi yang digunakan $\left(\mathrm{p}=0.0032^{*}\right)$ pada Gambar 4, setelah dianalisis hasil yang didapat yakni, responden tipe berkelompok-keluarga yang datang ke agrowisata dominan menggunakan kendaraan mobil (f:71) dan ada juga dengan pesawat (f:2). Sedangkan tipe berkelompok-teman yang datang ke agrowisata cenderung menggunakan bus (f:11) dan sepeda motor (f:21).

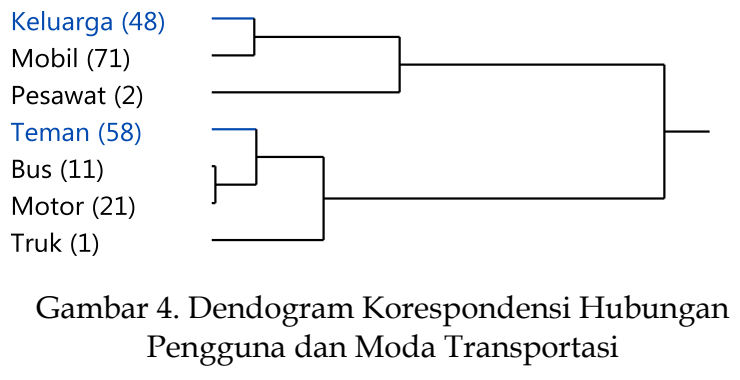

Hasil analisis korespondensi klaster antara jumlah mitra dan durasi kunjungan $\left(p=0.0042^{*}\right)$ pada Gambar 5, menunjukkan responden dengan jumlah mitra lebih dari 5 orang dan masuk sebagai tipe berkelompok-teman cenderung akan menghabiskan waktu selama lebih dari 3 jam (f:31). Sedangkan Berbeda halnya dengan responden yang datang ke agrowisata dengan jumlah mitra 2-5 orang dan termasuk dalam tipe berkelompok-keluarga waktu yang dihabiskan cenderung selama 1-3 jam saja (f:75).

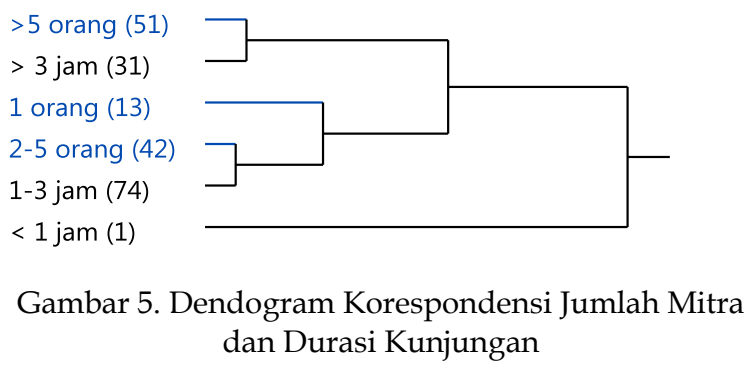

Terkait hasil analisis korespondensi klaster antara jumlah mitra dan jenis pekerjaan $\left(p=0.0176^{*}\right)$ pada Gambar 6, didapatkan bahwa responden dengan jumlah mitra lebih dari 5 orang maupun 1 orang dan masuk sebagai tipe berkelompok-teman memiliki jenis pekerjaan sebagai pegawai negeri (f:12), pengusaha/wirausaha (f:5) dan pegawai kontrak (f:5). Sedangkan responden yang datang ke agrowisata dengan jumlah mitra 2-5 orang dan termasuk dalam tipe berkelompok-keluarga didominasi dari mahasiswa/siswa (f:50), karyawan swasta (f:32) dan arsitek (f:2). 

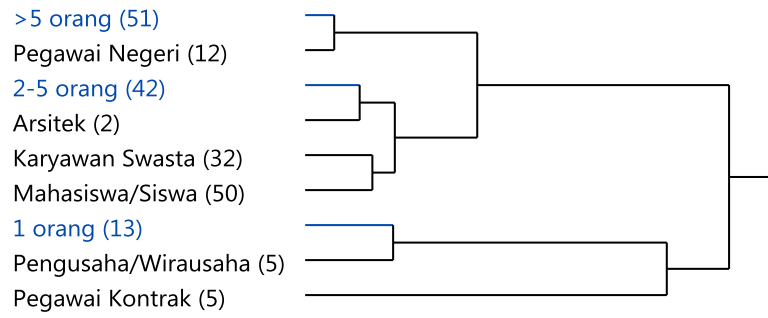

Gambar 6. Dendogram Korespondensi Jumlah Mitra dan Jenis Pekerjaan

\section{Model Hipotesis}

Setelah melakukan analisis korespondensi terhadap 5 pasang data kategori yang berbeda, yakni (1) antara kategori alasan berkunjung dan hubungan pengguna, (2) antara kategori hubungan pengguna dan jumlah mitra, (3) antara kategori hubungan pengguna dan moda transportasi, (4) antara kategori jumlah mitra dan durasi kunjungan, serta (5) antara jumlah mitra dan jenis pekerjaan, penelitian ini kemudian dilanjutkan dengan analisis selective coding. Pada analisis selective coding, ditemukan suatu pola terkait preferensi wisatawan dan tipe karakterisitk wisatawan yang berkunjung ke agrowisata. Pola tersebut dapat disusun menjadi model hipotesis yang dinamakan model hipotesis karakteristik wisatawan agrowisata. Berikut merupakan hasil penyusunan model hipotesis tersebut.

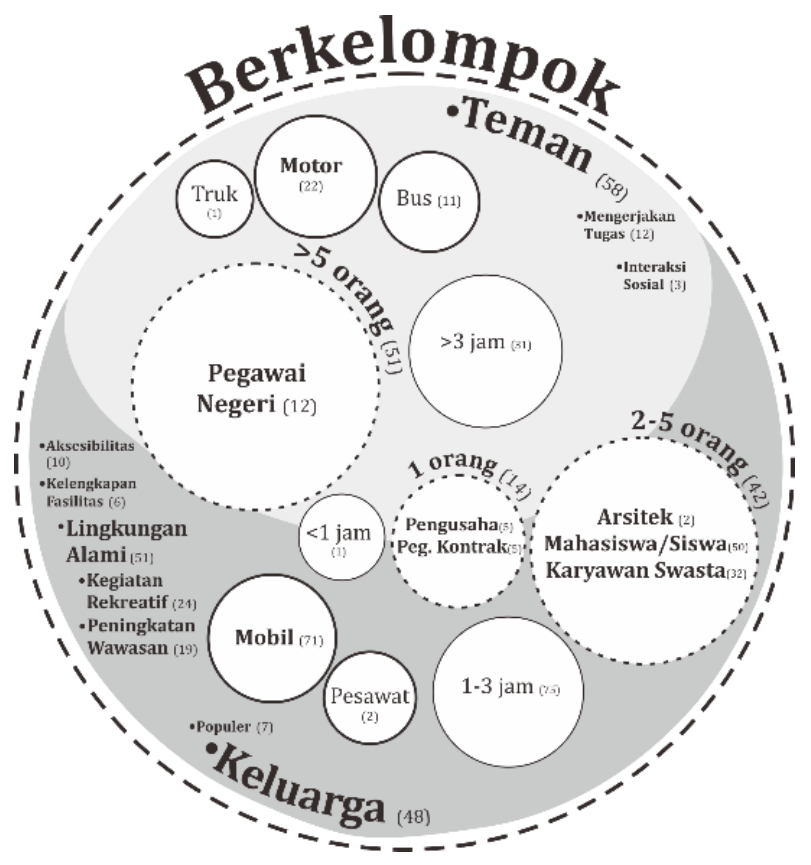

Gambar 7. Model Hipotesis Karakteristik Wisatawan Berkelompok yang Berkunjung ke Agrowisata

Karakteristik wisatawan yang berkunjung ke agrowisata berdasarkan model hipotesis pada Gambar 7 dapat dibedakan menjadi 2 tipe utama, yakni tipe berkelompok bersama keluarga dan berkelompok bersama dengan teman. Dalam Fitriani dan Sulistyani (2017) wisata yang melibatkan alam sebagai objek utamanya dapat dilakukan oleh beberapa individu, baik itu yang bepergian sendiri atau dalam tur kelompok-kelompok kecil.
Preferensi wisatawan tipe berkelompok-keluarga datang ke agrowisata cenderung dengan alasan karena tempatnya populer, lingkungan alami, kegiatan rekreatif dan peningkatan wawasan. Lingkungan alami yang dimaksud berkaitan dengan kondisi alam di agrowisata, contohnya sejuk, nyaman, alami dan dingin. Kegiatan rekreatif yang dimaksudkan oleh responden terkait liburan, refreshing, piknik dan berbelanja; sementara itu peningkatan wawasan berkaitan dengan alasan ingin tau dan menambah pengalaman baru. Ditinjau dari segi demografinya, segmentasi wisatawan berkelompokkeluarga biasanya terdiri dari 2-5 orang yang datang menggunakan kendaraan mobil. Tipe berkelompok yang terdiri dari 2-5 orang ini berada di lokasi selama 1 sampai 3 jam, adapun jenis pekerjaannya terdiri dari mahasiswa/siswa, karyawan swasta dan arsitek.

Tipe berkelompok-teman, memiliki preferensi untuk datang ke agrowisata dengan dominasi alasan untuk mengerjakan tugas. Pengerjaan tugas yang dimaksud oleh responden, berkaitan dengan tugas sekolah, tugas kuliah ataupun tugas kantor dengan objek utama yang dipelajari adalah agrowisata. Sementara itu, interaksi sosial berkaitan dengan alasan responden berkunjung untuk mengikuti acara kumpul bersama rekan. Demografi segmentasi wisatawan berkelompok-teman terdiri dari lebih 5 orang atau 1 orang yang datang menggunakan kendaraan bus dan sepeda motor, namun ada juga yang datang dengan menggunakan truk. Tipe berkelompokteman yang terdiri dari lebih 5 orang cenderung menghabiskan waktu di lokasi selama lebih dari 3 jam dengan jenis pekerjaannya sebagai pegawai negeri. Sementara itu, pengunjung yang datang bersama 1 orang teman cenderung menghabiskan waktu selama 1-3 jam dengan jenis pekerjaan sebagai pengusaha/wirausaha dan pegawai kontrak.

Adanya penggolongan wisatawan yang didominasi oleh tipe berkelompok dengan preferensi utama berupa lingkungan alami jika dibandingkan dengan klasifikasi tipologi wisatawan menurut Murphy dalam Nofyanti dan Sidiq (2016) termasuk dalam kelompok kognitif-normatif. Pengelompokan tipologi ini lebih menekankan pada motivasi yang melatarbelakangi keinginan wisatawan untuk melakukan perjalanan. Lingkungan alami (environment) merupakan bentuk motivasi eksternal yang menjadi faktor penarik (pull factor) untuk berwisata.

Berdasarkan Pitana dan Gayatri (2005) wisatawan yang menyukai kegiatan yang berhubungan dengan alam cenderung akan berwisata secara individual, namun dari hasil penelitian wisatawan yang berkunjung ke agrowisata didominasi dalam bentuk berkelompok. Hal ini menandakan bahwa tipologi wisatawan berdasarkan literatur memiliki kelemahan yang tidak dapat langsung digunakan untuk membagi tipe wisatawan. Menurut Nofyanti dan Sidiq (2016) kelemahan itu dikarenakan pembagian tipologi oleh para ahli terlalu bersifat statis dan deskriptif serta menggunakan generalisasi makro sehingga kurang memperhatikan situasi empiris mikro. Maka dari itu, untuk menghasilkan segmentasi yang lebih akurat harus didasarkan pada kondisi nyata dan dengan variabel yang bersifat multi dimensional.

Adanya dominasi preferensi lingkungan alami oleh wisatawan yang berkunjung ke agrowisata menjadikan unsur alam sebagai suatu kriteria penting yang harus diperhatikan dalam merancang sebuah kawasan 
agrowisata. Adapun kategori lingkungan alami yang dimaksud berkaitan erat dengan suatu kondisi yang berasal dari alam baik itu berupa hal yang dapat dinikmati secara visual, suasana ataupun segala bentuk yang berasal/tercipta oleh keberadaan alam tersebut. Contohnya udara yang sejuk, pemandangan perkebunan yang indah, pengalaman memetik buah serta tempat yang asri.

Selain lingkungan alami, kriteria perancangan agrowisata juga harus mempertimbangkan kategori kegiatan rekreatif (adanya lintasan untuk berjalan-jalan/tracking, tempat bersantai, serta berfoto), peningkatan wawasan berupa wisata edukatif (mulai dari tahap menanam sampai memanen tanaman dan proses pengolahan produk), serta kelengkapan fasilitas berupa wahana permainan outbound, wisata kuliner dan wisata berbelanja.

\section{SIMPULAN}

Berdasarkan hasil analisis dan pembahasan di atas, dapat disimpulkan bahwa preferensi kunjungan wisatawan ke kawasan agrowisata didasari oleh 8 (delapan) kategori besar, yakni lingkungan alami, kegiatan rekreatif, peningkatan wawasan, pengerjaan tugas, aksesibilitas, populer, kelengkapan fasilitas, dan interaksi sosial. Dominasi preferensi berasal dari kategori lingkungan alami yang tergolong sebagai motivasi faktor pendorong dan berasal dari eksternal individu (tempat/objek wisata). Preferensi tersebut jika dikorespondensikan dengan data kondisi demografi responden, didapatkan kecenderungan terkait tipe karakteristik wisatawan yang berkunjung ke agrowisata yang terbagi menjadi 2 kelompok besar, yaitu tipe berkelompok dan individual. Tipe berkelompok lebih mendominasi pengunjung yang datang dengan hubungan kedekatan keluarga dan teman. Terkait jumlah mitra yang biasanya diajak berkunjung terdiri dari 1 orang, 2-5 orang bahkan ada yang lebih dari 5 orang dengan rata-rata waktu yang dihabiskan di lokasi selama 1-3 jam. Transportasi yang dibawa cenderung menggunakan mobil dan motor.

Pengetahuan terkait preferensi dan tipe karakteristik wisatawan agrowisata tersebut dapat digunakan sebagai pendekatan untuk mengetahui secara riil segmentasi pasar yang akan disasar. Karakteristik wisatawan tersebut juga dapat digunakan sebagai dasar perimbangan untuk menentukan kriteria-kriteria fasilitas dalam perancangan agrowisata, sehingga perancangan yang dilakukan dapat memperhatikan keberlanjutan (lifecycle) objek wisata dilihat dari segi alam maupun aspek ekonominya.

\section{SARAN}

Penelitian ini dilaksanakan dengan pendekatan grounded theory, sehingga temuan penelitian memiliki nilai keaslian yang tinggi. Tetapi, data penelitian yang dikumpulkkan dengan metode non-random sampling serta jumlah responden yang terbatas menjadikan temuan menjadi kurang general. Untuk meningkatkan realibitas dan generalisasi data, diperlukan penelitian replikasi yang menggunakan metode random sampling agar pemilihan sampel dapat lebih representatif. Hal ini mengingat tingkat preferensi dan karakter wisatawan terhadap wisata alam, khususnya agrowisata akan cenderung berubah sesuai dengan pengalaman, keinginan, trend serta kondisi global yang sedang berlangsung.
Selain itu, diusulkan pula beberapa studi lanjutan terkait alasan pemilihan lingkungan alami serta jenis fasilitas yang sebaiknya disediakan terhadap tingkat kepuasan dan keinginan untuk berkunjung kembali ke kawasan agrowisata juga perlu dilakukan sebagai salah satu aspek yang paling dominan disampaikan oleh responden.

\section{DAFTAR PUSTAKA}

Assauri, S. 2015. Manajemen Pemasaran Edisi 15. Jakarta: Rajawali Perseda.

Babbie, E. 2007. The Practice of Social Research. United States of Ameriaca: Wadsworth Inc.

Cooper, C., Fletcher, J., Gilber, D., Fyall, A., Wanhill, S. 2005. Tourism Principles and Practice. New Jersey: Pearson Educaion Limited.

Creswell, J.W. 2007. Quantitative enquiry \& research design, choosing among five approaches. Book Vol. 2nd ed, data diperoleh melalui situs https://doi.org/10.1016/ j.aenj.2008.02.005. Diakses tanggal 13 Oktober 2020

Dradjat, H.A., Mugnisjah, W.Q. 2017. Pengelolaan Objek Wisata Pertanian Agrowisata Kampoeng Kopi Banaran, PT. Perkebunan Nusantara. Jurnal Lanskap Indonesia, 8(1), 21-26.

Febriana, N.P.R., Kaswanto, R.L.. 2015. Tourism Track Management of Cibeureum Waterfall as a Provider of Landscape Beautification Service at Gunung Gede Pangrango National Park. Procedia Environmental Sciences, 24 .

Fitriani, W., Sulistyani, A. 2017. Tipe Pengunjung Air Terjun Tujuh Tingkat di Desa Lubuk Ambacang Kecamatan Hulu Kuantan Kabupaten Kuantan Singingi. JOM FISIP, Vol.4 No.1, 1 - 12.

Ginting, M.S.B., Negara, I.M.K., Sudiarta, I.N. 2015. Analisis Segmentasi Pasar Wisatawan Mancanegara yang Berkunjung ke Bali dari Aspek Sosio-Ekonomi Demografi, Psikografi, dan Perilaku. Jurnal IPTA, Vol.3 No. 2, 98 - 101.

Kotler, P., Armstrong, G. 2006. Principles of Marketing Eleventh Edition. New Jersey: Prentice Hall International Inc.

Nofyanti, N.A., Sidiq, S.S. 2016. Tipologi Pengunjung di Kawasan Wisata Hapanasan Kabupaten Rokan Hulu. JOM FISIP, Vol.3 No.2, 1 - 16.

Pitana, I.G., Gayatri, P.G. 2005. Sosiologi Pariwisata. Yogyakarta: Andi.

Sunaryo, B. 2013. Kebijakan Pembangunan Destinasi Pariwisata Konsep dan Aplikasinya di Indonesia. Yogyakarta: Penerbit Gava Media.

Suprapti, W. 2010. Perilaku Konsumen Pemahaman Dasar dan Aplikasinya Dalam Strategi Pemasaran. Bali: Udayana University Press. 